\title{
Sleep Time Duration Does Not Affect Oral Inflammation and Periodontal Health Status in Night-Shift Workers: A Cross-Sectional Study [Retraction]
}

Roestamadji RI, Luthfi M, Surboyo MDC, Rumokoi RB, Khotimah FK. Nat Sci Sleep. 2020;12:1083-1090.

The Editor-in-chief and Publisher of Nature of Science and Sleep wish to retract the published article. Concerns were raised about the methodology and analysis of saliva melatonin and TNF-alpha described in the article. Some of these concerns are described below.

- The collection of a single saliva sample may not be sufficient for accurate melatonin analysis. Further, the 90 minute spread for saliva collection represents 2 half-lives of melatonin disappearance, and the differences between groups could simply be due to differences in the actual sampling times rather than a treatment effect.

- The values of saliva melatonin reported in the paper appear implausible. Table 4 reports the melatonin concentrations as $\mathrm{nmol} / \mathrm{ml}$ meaning the 200.52 $\mathrm{nmol} / \mathrm{ml}$ described would be $46,400 \mathrm{ng} / \mathrm{ml}$.

- The ELISA assay (E1013Hu, Bioassay Technology Laboratory, Shanghai, China) used to measure the melatonin is understood not to have been validated for use in saliva melatonin measurements.
- TNF- $\alpha$ is understood to be present in concentrations of $\mathrm{pg} / \mathrm{ml}$ and the levels reported in Table 4 appear implausible.

- The selection of the cases and controls is not clear, and the description of the study groups in the article is limited. The night-shift schedule is not described, with almost half of the shift workgroup described working only one-night shift per month, raising questions whether they could be considered shift workers.

The authors confirmed the reporting of melatonin values in Table 4 were incorrect and should have been ng/L, however they were unable to account for the other concerns that were raised. Thus, the findings could not be validated and the decision was made to retract the paper.

Our decision-making was informed by our policy on publishing ethics and integrity and the COPE guidelines on retraction.

The retracted article will remain online to maintain the scholarly record, but it will be digitally watermarked on each page as "Retracted".

\section{Publish your work in this journal}

Nature and Science of Sleep is an international, peer-reviewed, open access journal covering all aspects of sleep science and sleep medicine, including the neurophysiology and functions of sleep, the genetics of sleep, sleep and society, biological rhythms, dreaming, sleep disorders and therapy, and strategies to optimize healthy sleep.
The manuscript management system is completely online and includes a very quick and fair peer-review system, which is all easy to use. Visit http://www.dovepress.com/testimonials.php to read real quotes from published authors. 